\title{
Islet amyloid polypeptide: demonstration of mRNA in human pancreatic islets by in situ hybridization in islets with and without amyloid deposits
}

\author{
G.T. Westermark ${ }^{1}$, L. Christmanson ${ }^{1,3}$, G. Terenghi ${ }^{4}$, J.Permerth $^{2}$, C. Betsholtz ${ }^{3}$, J. Larsson ${ }^{2}$, J. M. Polak ${ }^{4}$ and $^{2}$ \\ P. Westermark ${ }^{1}$
}

'Department of Pathology, University of Linköping, Linköping, Sweden

${ }^{2}$ Department of Surgery, University of Linköping, Linköping, Sweden

${ }^{3}$ Department of Pathology, University of Uppsala, Uppsala, Sweden

${ }^{4}$ Department of Histochemistry, Royal Postgraduate Medical School, Hammersmith Hospital, London, UK

\begin{abstract}
Summary. Islet amyloid polypeptide which is normally coexpressed with insulin in beta cells, forms amyloid deposits especially in islets of Type 2 (non-insulin-dependent) diabetic subjects. Occurrence of islet amyloid is paradoxically associated with loss of islet amyloid polypeptide immunoreactivity in beta cells. The present study was undertaken to examine whether the islet amyloid polypeptide gene is expressed in islets with decreased islet amyloid polypeptide immunoreactivity. Pancreatic tissue from 14 patients, 7 with Type 2 diabetes and 7 non-diabetic, were obtained at autopsy or surgery and studied for islet amyloid polypeptide expression by in situ hybridization and for presence of insulin and islet amyloid polypeptide by immunohistochemistry. Six of the specimens from the diabetic and three of those from the nondiabetic patients had varying degrees of islet amyloid polypeptide-derived islet amyloid. Amyloid deposits were associated with decreased numbers of beta cells with islet amyloid polypeptide immunoreactivity despite an apparent normal
\end{abstract}

frequency of insulin-containing cells. This discrepancy might reflect an alteration in islet amyloid polypeptide production or processing at a transcriptional or post-transcriptional level. In contrast to the varying immunohistochemical patterns, islets of all categories showed strong labelling using an islet amyloid polypeptide probe for in situ hybridization. It is concluded that islet amyloid polypeptide production is not altered at the transcriptional level. The following possibilities remain: (1) islet amyloid polypeptide production may be altered at a post-transcriptional level or (2) that islet amyloid polypeptide production is normal but the reduced immunoreactivity of the cells reflects a reduced storage of IAPP in secretory granules. We favour the second possibility since islet amyloid deposition is incompatible with reduced islet amyloid polypeptide synthesis.

Key words: Islet amyloid polypeptide, deposits, fibrils, in situ hybridization, expression, immunohistochemistry.
Islet amyloid polypeptide (IAPP) is a 37-amino-acidresidue polypeptide, discovered through its ability to form amyloid deposits in the islets of Langerhans in Type 2 (noninsulin-dependent) diabetes mellitus and in many insulinomas [1-4]. It is stored together with insulin in the secretory granules [5-7] as early as during gestation [8] and the two substances are released together after beta-cellstimulation with glucose or other secretagogues [9-11]. Although IAPP and insulin are normally secreted in parallel, the plasma level of IAPP is only about $1-10 \%$ of that of insulin [10, $12,13]$. Under experimental conditions, a dissociation of the expression of the two polypeptides has been seen [14]. In humans IAPP is encoded by a gene located on chromosome 12 and expressed as an 89 amino-acid-residue prepropolypeptide in which IAPP is flanked by two short propeptides [15-17]. Processing to mature IAPPincludes cleavage at double basic amino acid residues and C-terminal amidation. The way in which IAPP expression is regulated in relation to that of insulin is at present not known.
The normal function of IAPP has not been defined. Experimentally, IAPP has interesting effects on the utilization of glucose in skeletal muscle in that both basal and insulin-stimulated glycogen synthesis is inhibited $[18,19]$. At least some of these effects depend on decreased glucose transport [20]. Given intravenously, IAPP can give rise to insulin resistance in experimental animals $[21,22]$. However, slightly contradictory results have been obtained and it should be noted that the plasma levels of IAPP found normally are much lower than the levels needed for the described experimental effects [23].

In normal adult human and rat pancreas, all beta cells are IAPP-positive in immunohistochemistry $[2,8]$, although the staining intensity varies. In Type 2 diabetes in humans, and in the diabetic cat, IAPP-derived islet amyloid develops in most individuals. Since islet amyloid is a concentrated form of IAPP, one might expect an increased synthesis of IAPP in affected islets. Paradoxically however, most beta cells are negative for IAPP immu- 
noreactivity in human Type 2 diabetes and in diabetic cats, at least in islets containing amyloid deposits [24, 25]. This is in contrast to the situation regarding insulin for which the islets are still immunoreactive and may indicate that following the development of amyloid, the beta cells enter a state in which the insulin but not the IAPP gene is transcribed. Alternatively, IAPP mRNA is produced but less efficiently translated. A third possibility is that IAPP may be synthesized at a normal rate but becomes rapidly released instead of being stored in secretory granules. The present immunohistochemical and in situ hybridization study was performed in order to discriminate between an alteration at a transcriptional or post-transcriptional level.

\section{Materials and methods}

Pancreatic tissue. Pancreatic tissue (corpus or cauda) was obtained at autopsy $3-7 \mathrm{~h}$ after the death of seven patients with a history of Type 2 diabetes and five non-diabetic individuals (Tables 1 and 2). In the non-diabetic group several urine tests for glucose had been performed with negative results and in most cases at least one glucose determination with a normal result. Pancreatic tissue from the corpus was also obtained from two patients undergoing subtotal pancreatic resection. One of these patients had pancreatic carcinoma while the other had an ulcer penetrating into the head of the pancreas. Both the patients had normal glucose tolerance. In all instances the specimens were immediately placed on ice and small pieces of the macroscopically normal body of the pancreas were fixed in ice-cold buffered neutral $4 \%$ formaldehyde solution. After fixation for about $6 \mathrm{~h}$, the specimens were dehydrated and embedded in paraffin.

Amyloid. Amyloid was identified by alkaline Congo red staining of deparaffinized sections. The sections were studied in polarized light for green birefringence. The percentage of islets containing any amyloid was determined on sections double-stained for amyloid with Congo red and for insulin with the peroxidase-antiperoxidase method (see below). All islets in the section, irrespective of size, were included. At least 100 islets were studied in each case.

Immunohistochemistry. Peroxidase-conjugated avidin, biotinylated swine anti-rabbit immunoglobulins, swine anti-rabbit immunoglobulins cross-reacting with guinea pig immunoglobulins and rabbit horseradish peroxidase anti-horseradish peroxidase complex were from Dakopatts (Copenhagen, Denmark). Antiserum to porcine insulin, produced in a guinea pig (Ma37), has been described previously [26]. Antiserum to human APP $_{1-37}$ (AA116) was raised in a rabbit by standard methods using synthetic human IAPP [20]. IAPP was linked to keyhole limpet haemocyanin [24]. When used in immunohistochemistry on pancreatic sections from human, cat and rat, antiserum AA116 labelled islet beta cells specifically and strongly. This reaction was abolished when the antiserum was preabsorbed $(10 \mathrm{mg} / \mathrm{ml}$ of undiluted antiserum $)$ with the synthetic human IAPP $_{1-37}$. Deparaffinized sections were incubated with the primary antiserum (diluted 1:200-1:400 for AA116 and 1:800-1:1600 for Ma37) overnight at room temperature. For demonstration of IAPP immunoreactivity, the avidin-biotin method [27] was used while insulin immunoreactivity was demonstrated by the peroxidaseantiperoxidase method [28]. The reactions were visualized with diaminobenzidine (Sigma, St.Louis, Mo., USA). For control, the primary antisera were replaced with normal rabbit serum. Semiquantitative estimation of the proportions of immunoreactive cells was performed as described [24].

Probe. A cDNA clone of human preprolAPP has been described previously [16]. A 320 base pair long probe corresponding to the full length coding region of IAPP was amplified by polymerase chain reaction. The RNA polymerase specific Sp6 and $\mathrm{T} 7$ promoters were linked to the sense and antisense primers, respectively. A digoxigenated riboprobe was generated by in vitro transcription [29]. Unlabelled nucleotides (NTP) and T7 and Sp6 polymerases were from Pharmacia (Uppsala, Sweden) and digoxigenated UTP and human placenta ribonuclease inhibitor from Boehringer (Mannheim, FRG).

In situ hybridization. This was mainly performed as described previously $[29,30]$. Deparaffinized sections, placed on glass slides, were immersed in PBS-Triton $(0.15 \mathrm{~mol} / 1 \mathrm{NaCl}-0.01 \mathrm{~mol} / \mathrm{l}$ sodium phosphate, $\mathrm{pH} 7.5$, containing $0.2 \%$ Triton $\mathrm{X}-100)$ and thereafter rinsed in phosphate buffered saline (PBS). Proteinase K (Boehringer) digestion $(1 \mathrm{mg} / \mathrm{ml}$ in $0.1 \mathrm{~mol} / \mathrm{l}$ Tris $\mathrm{HCl}$ buffer, $\mathrm{pH} 8.0-50 \mathrm{mmol} / 1$ EDTA) was performed at $37^{\circ} \mathrm{C}$ for $10 \mathrm{~min}$. The digestion was stopped by immersion in $0.1 \mathrm{~mol} / \mathrm{l}$ glycine in PBS for $5 \mathrm{~min}$. The sections were post-fixed in $4 \%$ paraformaldehyde-PBS for $3 \mathrm{~min}$, rinsed briefly in PBS, immersed in $0.25 \%$ acetic anhydride $-0.1 \mathrm{~mol} / \mathrm{l}$ triethanolamine solution, $\mathrm{pH} 8.0$ for $10 \mathrm{~min}$, rinsed briefly in water and prehybridized at $50^{\circ} \mathrm{C}$ for $30 \mathrm{~min}$. The hybridization buffer contained $50 \%$ formamide, $5 \times \mathrm{SSC}$ ( $=0.75 \mathrm{~mol} / \mathrm{l}$ sodium chloride and $0.25 \mathrm{~mol} / 1$ sodium citrate), $10 \%$ dextran sulphate, $5 \times$ Denhardt's solution $(100 \times=2 \%$ Ficoll, $2 \%$ polyvinylpyrrolidone, and $2 \%$ bovine serum albumin), $2 \%$ sodium dodecyl sulphate (SDS), and $100 \mu \mathrm{g} / \mathrm{ml}$ denatured sheared herring sperm DNA (Boehringer). The probe concentration was $2.5 \mathrm{ng} / \mu \mathrm{l}$ and $10 \mu \mathrm{l}$ were applied to each section. Hybridization was performed with the digoxigenin-labelled probe under a coverslip overnight at $50^{\circ} \mathrm{C}$. For control, sections were (1) treated with RNase before hybridization, (2) hybridized with two digoxigenized non-related probes (a prolactin sense probe and an IAPP sense probe) or (3) treated identically without addition of any probe.

Table 1. Demonstration of islet amyloid polypeptide (IAPP) and insulin by immunohistochemistry and of IAPP mRNA by in situ hybridization in pancreatic tissue from non-diabetic subjects. The immunohistochemical reactions with islet cells were semiquantitatively estimated

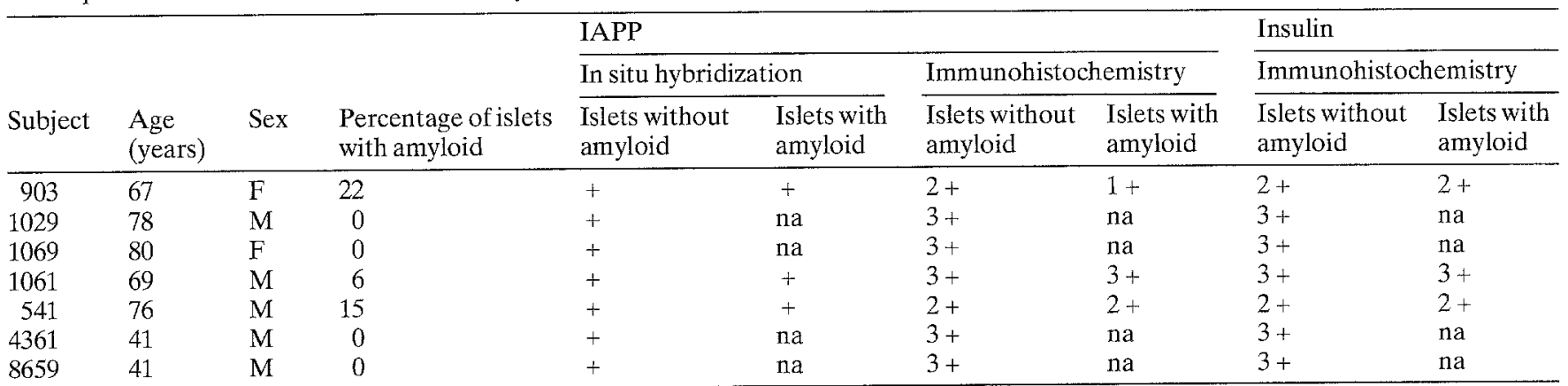

$0=$ no, $1+=<10 \%, 2+=10-50 \%$ and $3+=>50 \%$ immunoreactive cells, respectively. na, Not applicable. The hybridization reactions were not graded 
After hybridization, the sections were washed extensively in $2 \times$ SSC- $0.1 \%$ SDS followed by $0.1 \times$ SSC- $0.1 \%$ SDS. Thereafter, the sections were treated with RNase (Boehringer) $(10 \mathrm{mg} / \mathrm{ml}$ in $2 \times \mathrm{SSC}$ ) at $37^{\circ} \mathrm{C}$ for $15 \mathrm{~min}$. The sections were rinsed in $2 \times \mathrm{SSC}$ and incubated with alkaline phosphatase-labelled anti-digoxigenin antibodies (Boehringer) for 4-12 h. They were then washed and the reaction was visualized with nitro blue tetrazolium chloride and 5-bromo-4-chloro-3-indolyl-phosphate in a solution containing $0.1 \mathrm{~mol} / \mathrm{l}$ Tris $\mathrm{HCl}, \mathrm{pH} 9.5,0.1 \mathrm{~mol} / \mathrm{l} \mathrm{NaCl}, 50 \mathrm{mmol} / 1 \mathrm{MgCl}_{2}$ buffer and levamisole $(25 \mathrm{mg} / 100 \mathrm{ml})$. The reaction was stopped in $20 \mathrm{mmol} / \mathrm{l}$ TrisHCl-5 mmol/l EDTA, pH 7.5 .

The in situ hybridization and immunohistochemical stainings were always performed on three consecutive sections.

\section{Results}

\section{Amyloid}

Islet amyloid was found in six of the diabetic and three of the non-diabetic patients (Tables 1 and 2). Extensive deposits in a majority of islets were found in five of the diabetic patients.

\section{Islet amyloid polypeptide and insulin immunoreactivity}

Non-diabetic patients. The results of the immunohistochemical study are shown in Table 1 . In islets without amyloid, antiserum to IAPP labelled most of the islet cells with a pattern resembling that of insulin immunostaining. However, the variation in strength of staining between cells was much greater with antiserum to IAPP compared with antiserum to insulin. Cellular processes were often evident (Fig.1). Also islets with amyloid deposits contained many IAPP immunoreactive cells. Only in one case was there a reduced number of IAPP-positive cells in amyloid containing islets.

Diabetic patients. The immunohistochemical findings are given in Table 2 . The frequency of insulin-positive cells was not greatly reduced, not even in islets with amyloid (Table 2; Fig. 2a). The insulin-reaction in the individual beta cells was as strong as in islets of non-diabetic individuals. In contrast, a clearly reduced frequency of IAPPpositive cells was seen in amyloid-free islets in most of the

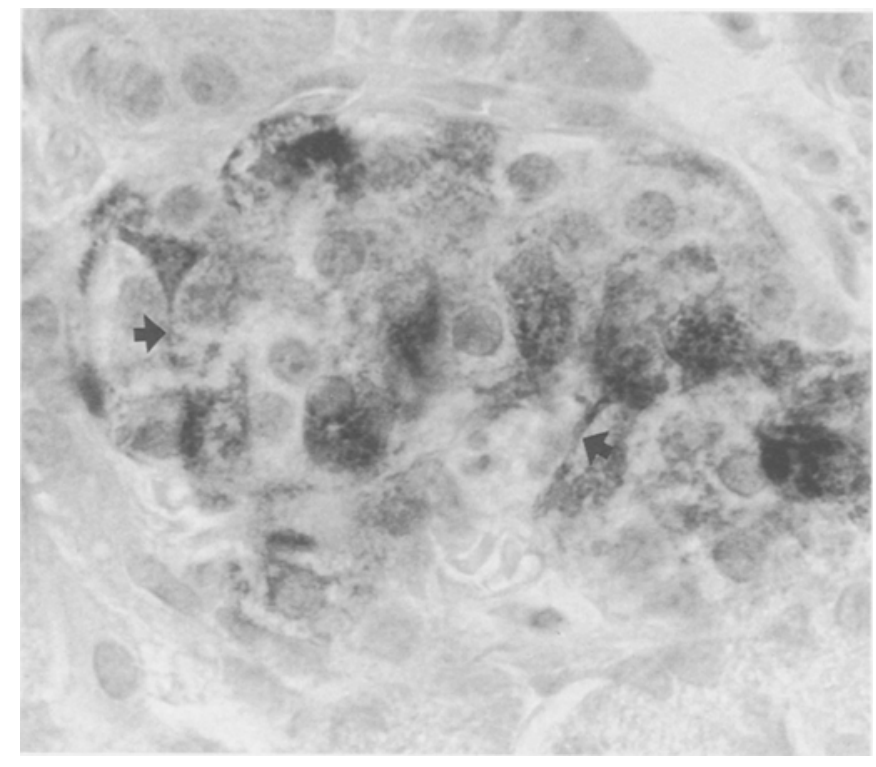

Fig.1. Normal islet, immunostained for IAPP. The beta cells show a notable variation in IAPP-labelling. Some slender labelled cytoplasmic extensions (arrows) are apparent. Magnification $\times 930$

patients. Even more evident was the discrepancy between the number of insulin and IAPP-positive cells in islets with amyloid deposits (Fig. 2b). In the islets of two of the patients, no IAPP-containing cells were found while in four, only a few scattered cells occurred.

\section{In situ hybridization}

In normal pancreatic tissue, in situ hybridization with the IAPP probe resulted in strong labelling of most of the islet cells (Fig. 3b). The label was confined to the cytoplasm and was often stronger in parts of the cells. The labelling pattern was similar to that seen immunohistochemically with antisera to IAPP (Fig. $3 \mathrm{a}$ ) and insulin (not shown). The labelling intensity varied somewhat between cells. The exocrine parenchymal cells showed no label. The specificity of the reaction was verified by hybridization following RNase treatment or after hybridization with the

Table 2. Demonstration of islet amyloid polypeptide (IAPP) and insulin by immunohistochemistry and of IAPP mRNA by in situ hybridization in pancreatic tissue from Type 2 diabetic subjects. The immunohistochemical reactions with islet cells were semiquantitatively estimated

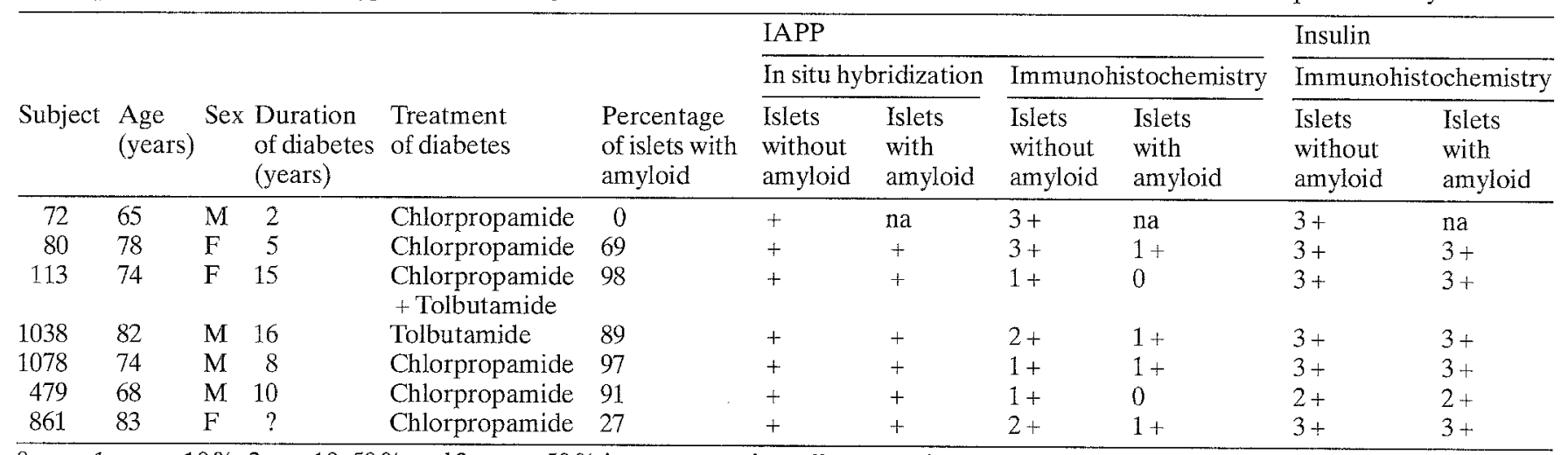

$0=$ no, $1+=<10 \%, 2+=10-50 \%$ and $3+=>50 \%$ immunoreactive cells, respectively. na, Not applicable. The hybridization reactions were not graded 

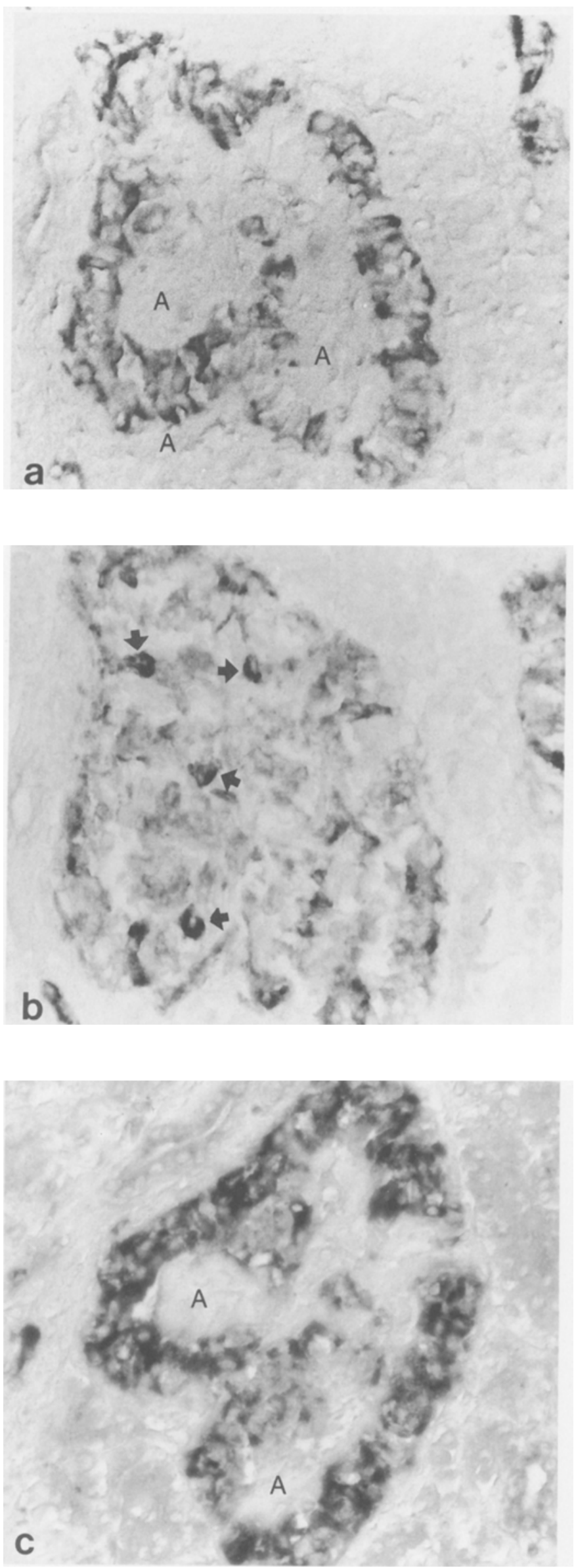

sense probes. These procedures gave negative results as did omission of the probe.

In pancreases with islet amyloid deposits from both diabetic and non-diabetic patients, the majority of islet cells also showed positive in situ hybridization. This signal varied somewhat from tissue to tissue but no attempt was made to quantitate the reaction. In contrast to the immunohistochemical findings, islets with amyloid deposits, including those of the diabetic patients with pronounced islet amyloidosis, exhibited a strong IAPP signal (Fig. 2c) which did not differ significantly from that seen in islets without amyloid in diabetic and non-diabetic patients. The signal was similar to the pattern obtained with the immunohistochemical staining for insulin (Fig. 2a).

\section{Discussion}

The human pancreas is comparatively difficult to study histologically due to the problems in obtaining tissue suitable for immunohistochemistry. The availability of fresh specimens is limited and for post-mortem material to be useful, autopsy must be performed very soon after death. Nevertheless, autopsy material is sometimes useful, even for mRNA hybridization, as shown in the present study with an IAPP probe and as previously shown for insulin mRNA [31].

IAPP is selectively stored in the beta cells in the human pancreas [8,24], and in normal tissue IAPP and insulin immunoreactivities are distributed identically. We do not know exactly why IAPP gives rise to amyloid in Type 2 diabetes. One important factor is the primary structure within a central segment of the human (and cat) IAPP molecule which determines its ability to aggregate as amyloid fibrils $[16,32]$. One other factor may be an overproduction of the polypeptide. This possibility has been supported by the finding of an increased IAPP immunoreactivity in the beta cells of glucose intolerant but not overtly diabetic cats [25]. It has therefore been surprising that instead of increased immunoreactivity, a greatly reduced beta-cell IAPP immunoreactivity occurs in Type 2 diabetes in humans [24] and in diabetic cats [25]. The most important finding in the present investigation is therefore that IAPP mRNA is present in beta cells in islets with amyloid deposits, whether light or heavy, and to the same extent as in normal islets, as far as can be judged from in situ hybridization.

The absence of IAPP immunoreactivity despite the presence of IAPP mRNA can be due to two possible mechanisms. One possibility is that transcription of the IAPP gene occurs but with no or with only a very low degree of translation. The other possibility is that there is an

Fig. 2a-c. Consecutive sections of an islet, rich in amyloid (A), from a Type 2 diabetic patient. a The section was immunostained for insulin and $\mathbf{b}$ for IAPP. Only few of the insulin-labelled cells in a react with the antiserum to IAPP (arrows). c The same islet (slightly rotated) was subjected to in situ hybridization with an IAPP probe as in Figure 1. The distribution of the reaction product is identical with the staining pattern for insulin but differs dramatically from the labelling pattern with the antiserum to IAPP. Magnification $\times 370$ 

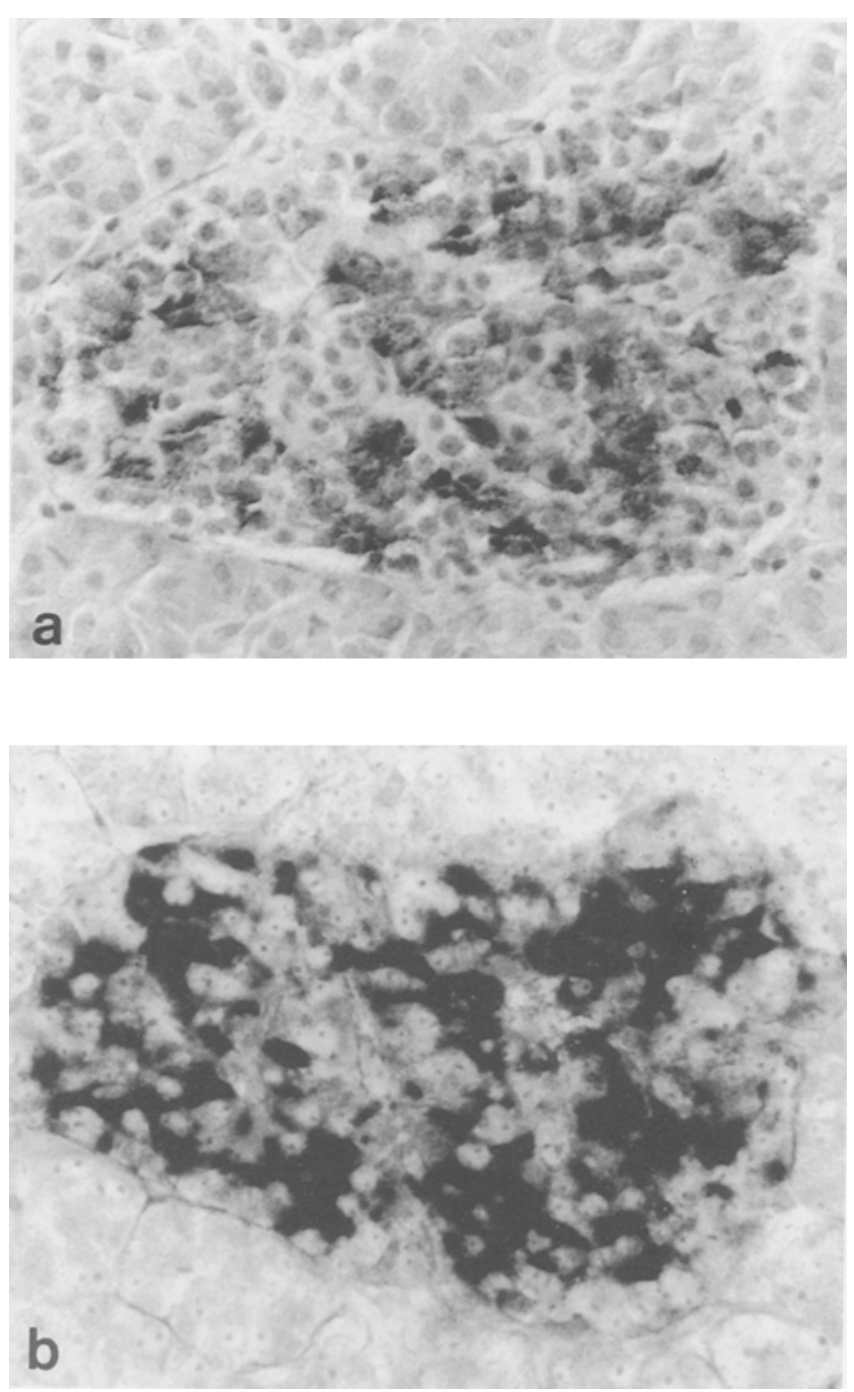

Fig.3a, b. Normal islet from a non-diabetic patient, a immunostained for IAPP and b subjected to in situ hybridization with an IAPP probe, visualized with immunohistochemistry. Note a similar distribution of the reaction products. Magnification $\times 370$

on-going IAPP production but that normal storage of IAPP in secretory granules is hindered. Although the latter explanation remains to be confirmed, it seems to be the most plausible for at least two reasons. Firstly, in one study it was found that the amount of islet amyloid increases with the duration of diabetes [33] for which an on-going production of IAPP is a prerequisite. Secondly, the plasma levels of IAPP in Type 2 diabetic patients are not significantly lower as compared to non-diabetic subjects $[10,13]$. However, further studies are needed to elucidate the exact nature of cellular abnormality leading to loss of IAPP immunoreactivity in beta cells and to islet amyloid.

All diabetic patients had been treated with sulphonylureas. Whether such treatment affects IAPP expression or secretion is still to be studied.

Acknowledgements. This study was supported by the Swedish Medical Research Council, the Nordic Insulin Fund and the Swedish Cancer Society.

\section{References}

1. Westermark P, Wernstedt C, Wilander E, Sletten K (1986) A novel peptide in the calcitonin gene related peptide family as an amyloid fibril protein in the endocrine pancreas. Biochem $\mathrm{Bi}$ ophys Res Commun 140: 827-831

2. Westermark P, Wernstedt C, Wilander E, Hayden DW, O'Brien TD, Johnson KH (1987) Amyloid fibrils in human insulinoma and islets of Langerhans of the diabetic cat are derived from a neuropeptide-like protein also present in normal islet cells. Proc Natl Acad Sci USA 84: 3881-3885

3. Westermark P, Wernstedt C, O'Brien TD, Hayden DW, Johnson KH (1987) Islet amyloid in type 2 human diabetes mellitus and adult diabetic cats contains a novel putative polypeptide hormone. Am J Path 127: 414-417

4. Cooper GJ, Willis AC, Clark A, Turner AC, Sim RB, Reid KBM (1987) Purification and characterization of a peptide from amyloid-rich pancreases of type 2 diabetic patients. Proc Natl Acad Sci USA 84: 8628-8632

5. Johnson KH, O'Brien TD, Hayden DW et al. (1988) Immunolocalization of islet amyloid polypeptide (IAPP) in pancreatic beta cells by means of peroxidase-antiperoxidase (PAP) and protein A-gold techniques. Am J Path 130:1-8

6. Lukinius A, Wilander E; Westermark GT, Engström U, Westermark P (1989) Co-localization of islet amyloid polypeptide and insulin in the $\mathrm{B}$ cell secretory granules of the human pancreatic islets. Diabetologia 32: 240-244

7. Clark A, Edwards CA, Ostle LR et al. (1989) Localisation of islet amyloid peptide in lipofuscin bodies and secretory granules of human B-cells and in islets of type-2 diabetic subjects. Cell Tissue Res 257: 179-185

8. Rindi G, Terenghi G, Westermark G, Westermark P, Moscoso G, Polak JM (1991) Islet amyloid polypeptide in proliferating pancreatic B cells during development, hyperplasia, and neoplasia in humans and mice. Am J Path 138: 1321-1334

9. Hartter E, Svoboda T, Ludvik B et al. (1991) Basal and stimulated plasma levels of pancreatic amylin indicate its co-secretion with insulin in humans. Diabetologia 34: 52-54

10. Butler PC, Chou J, Carter WB et al. (1990) Effects of meal ingestion on plasma amylin concentration in NIDDM and nondiabetic humans. Diabetes 39: 752-756

11. Kahn SE, D'Alessio DA, Schwartz MW et al. (1990) Evidence of cosecretion of islet amyloid polypeptide and insulin by b-cells. Diabetes 39: 634-638

12. Nakazato M, Asai J, Kangawa K, Matsukura S, Matsuo H (1989) Establishment of radioimmunoassay for human islet amyloid polypeptide and its tissue content and plasma concentration. Biochem Biophys Res Commun 164: 394-399

13. Sanke T, Hanabusa T, Nakano Y et al. (1991) Plasma islet amyloid polypeptide (amylin) levels and their responses to oral giucose in type 2 (non-insulin-dependent) diabetic patients. Diabetologia 34: $129-132$

14. Madsen OD, Nielsen JH, Micheisen B et al. (1991) Islet amyloid polypeptide and insulin expression are controlled differently in primary and transformed islet cells. Mol Endocrinol 5: 143-148

15. Sanke T, Bell GI, Sample C, Rubenstein AH, Steiner DF (1988) An islet amyloid peptide is derived from an 89-amino acid precursor by proteolytic processing. J Biol Chem 263: 17243-17246

16. Betsholtz C, Svensson V, Rorsman F et al. (1989) Islet amyloid polypeptide (IAPP): cDNA cloning and identification of an amyloidogenic region associated with species-specific occurrence of age-related diabetes mellitus. Exp Cell Res 183:484-493

17. Mosselman S, Höppener JWM, Lips CJM, Jansz HS (1989) The complete islet amyloid polypeptide precursor is encoded by two exons. FEBS Lett 247: 154-158

18. Leighton B, Cooper GJS (1988) Pancreatic amylin and calcitonin gene-related peptide cause resistance to insulin in skeletal muscle in vitro. Nature 335: 632-635

19. Leighton B, FootE (1990) The effects of amylin on carbohydrate metabolism in skeletal muscle in vitro and in vivo. Biochem $\mathrm{J} 269$ : $19-23$ 
20. Zierath JR, Galuska D, Engström $\AA$ et al. (1992) Human islet amyloid polypeptide at pharmacological levels inhibits insulin and phorbol ester-stimulated glucose transport in in vitro incubated human muscle strips. Diabetologia 35:26-31

21. Johnson KH, O'Brien TD, Jordan K, Betsholtz C, Westermark P (1990) The putative hormone islet amyloid polypeptide (IAPP) induces impaired glucose tolerance in cats. Biochem Biophys Res Commun 167: 507-513

22. Sowa R, Sanke T, Hirayama J et al. (1990) Islet amyloid polypeptide amide causes peripheral insulin resistance in vivo in dogs. Diabetologia 33: 118-120

23. Westermark P, Johnson KH, O'Brien TD, Betsholtz C (1992) Islet amyloid polypeptide - a novel controversy in diabetes research. Diabetologia 35: 297-303

24. Westermark P, Wilander E, Westermark GT, Johnson KH (1987) Islet amyloid polypeptide-like immunoreactivity in the islet $B$ cells of type 2 (non-insulin-dependent) diabetic and non-diabetic individuals. Diabetologia 30: 887-892

25. Johnson KH, O'Brien TD, Jordan K, Westermark P (1989) Impaired glucose tolerance is associated with increased islet amyloid polypeptide (IAPP) immunoreactivity in pancreatic beta cells. Am J Path 135: 245-250

26. Westermark P, Wilander E (1983) Islet amyloid in type 2 (non-insulin-dependent) diabetes is related to insulin. Diabetologia 24 : 342-346

27. Hsu SM, Raine L, Fanger H (1981) Use of avidin-biotin-peroxidase complex $(\mathrm{ABC})$ in immunoperoxidase techniques: a comparison between $\mathrm{ABC}$ and unlabeled antibody (PAP) procedures. J Histochem Cytochem 29:577-580

28. Sternberger LA (1979) Immunocytochemistry (2nd edn.). John Wiley, New York
29. Gibson SJ, Polak JM (1990) Principles and applications of complementary RNA probes. In: Polak JM, McGee JO (eds) In situ hybridization. Principles and practice. Oxford University Press, Oxford, pp 81-94

30. Cox KH, DeLeon DV, Angerer LM, Angerer RC (1984) Detection of mRNAs in sea urchin embryos by in situ hybridization using asymmetric RNA probes. Develop Biol 101: 485-502

31. Shorrock K, Roberts P, Pringle JH, Lauder I (1991) Demonstration of insulin and glucagon mRNA in routinely fixed and processed pancreatic tissue by in-situ hybridization. J Path 165: 105110

32. Westermark P, Engström U, Johnson KH, Westermark GT, Betsholtz C (1990) Islet amyloid polypeptide: pinpointing amino acid residues linked to amyloid fibril formation. Proc Natl Acad Sci USA 87: 5036-5040

33. Westermark P, Grimelius L (1973) The pancreatic islet cells in insular amyloidosis in human diabetic and non-diabetic adults. Acta Path Microbiol Scand A 81: 291-300

Received: 8 September 1992

and in revised form: 19 November 1992

Prof. P. Westermark

Department of Pathology

Faculty of Health Sciences

University Hospital

S-581 85 Linköping

Sweden 